\title{
Winogradskyella rapida sp. nov., isolated from protein-enriched seawater
}

\author{
Jarone Pinhassi, ${ }^{1}$ Olga I. Nedashkovskaya, ${ }^{2}$ Åke Hagström ${ }^{1}$ \\ and Marc Vancanneyt ${ }^{3}$ \\ ${ }^{1}$ Marine Microbiology, Department of Pure and Applied Natural Sciences, University of Kalmar, \\ SE-39182 Kalmar, Sweden \\ ${ }^{2}$ Pacific Institute of Bioorganic Chemistry of the Far-Eastern Branch of the Russian Academy of \\ Sciences, Pr. 100 Let Vladivostoku 159, 690022 Vladivostok, Russia \\ ${ }^{3}$ BCCM/LMG Bacteria Collection and Laboratory of Microbiology, Ghent University, \\ Ledeganckstraat 35, B-9000 Ghent, Belgium
}

Correspondence Jarone Pinhassi jarone.pinhassi@hik.se
Members of the phylum Bacteroidetes make up a significant portion (up to $30 \%$ ) of marine bacterioplankton communities (Glöckner et al., 1999). Notably, members of the family Flavobacteriaceae account for a majority of the phylogenetic diversity found among marine Bacteroidetes (Alonso et al., 2007). Members of the phylum Bacteroidetes in general, and members of the family Flavobacteriaceae in particular, have been implicated in the degradation of complex organic matter in the sea (Abell \& Bowman, 2005; Kirchman, 2002; Pinhassi et al., 2004). Cottrell \& Kirchman (2000) highlighted that marine members of the Bacteroidetes have a preference for the utilization of protein over that of simple monomers. Understanding the taxonomy and the phenotypic characteristics of bacteria that potentially participate in the degradation of organic matter in the sea is an important step in understanding how biogeochemical processes are regulated.

Strain $\mathrm{SCB}^{\mathrm{T}}{ }^{\mathrm{T}}$ was isolated from a seawater mesocosm experiment designed to investigate how a natural bacterio-

The GenBank/EMBL/DDBJ accession number for the $16 \mathrm{~S}$ rRNA gene sequence of strain $\mathrm{SCB}^{\mathrm{T}}{ }^{\mathrm{T}}$ is $\mathrm{U} 64013$.

Rates of growth and protease activity for strain $\mathrm{SCB}^{\top}{ }^{\top}$ and a scanning electron micrograph of bacterial cells are available as supplementary material with the online version of this paper. plankton community would respond to protein enrichment (Pinhassi et al., 1999). Enrichment with protein (BSA) was chosen in an attempt to simulate the release of organic matter during the decay phase of a phytoplankton bloom. Surface seawater was collected on 7 December 1995 from Scripps Pier, Southern California Bight (La Jolla, CA, USA; $32^{\circ} 53^{\prime} \mathrm{N} 117^{\circ}$ $15^{\prime} \mathrm{W}$ ). The sample was incubated for 3 days at $15{ }^{\circ} \mathrm{C}$ with a $12 \mathrm{~h}$ dark $/ 12 \mathrm{~h}$ light cycle, after which agar plates were prepared for strain isolation as described previously by Pinhassi et al. (1999). Strain SCB36 ${ }^{\mathrm{T}}$ was one of the bacteria that exhibited the most pronounced positive growth response to enrichment with protein and reached net growth rates of nearly 1.5 day $^{-1}$ (see Supplementary Fig. S1, available in IJSEM Online), compared to net growth rates below 0.4 day $^{-1}$ for the total bacterial community (Pinhassi et al., 1999). Further, its growth rate closely followed the increase in hydrolytic ectoenzyme activity measured in the mesocosms, particularly that of protease activity (Supplementary Fig. S1). Together with some other flavobacteria species, strain SCB $36^{\mathrm{T}}$ increased in abundance even though it was in competition with other members of the bacterial community and exposed to active protozoan grazing, indicating its high growth potential when supplied with protein.

For strain isolation, $0.1 \mathrm{ml}$ of $1 / 100$-diluted sample water from the protein-enriched seawater mesocosm was spread 
onto ZoBell agar plates prepared from seawater from the Southern California Bight. Yellow colonies grew on these plates with an abundance of approximately $1 \times 10^{3}$ c.f.u. $\mathrm{ml}^{-1}$. After primary isolation and purification, strain SCB $36^{\mathrm{T}}$ was cultivated at $23{ }^{\circ} \mathrm{C}$ on the same medium and stored at $-80{ }^{\circ} \mathrm{C}$ in ZoBell medium with $25 \%$ (v/v) glycerol. For subsequent culturing of strain $\mathrm{SCB} 36^{\mathrm{T}}$, marine broth/agar 2216 (MB/MA; Difco) was used unless otherwise stated.

Determination of growth at different temperatures, nitrate reduction, acid production from carbohydrates, production of hydrogen sulfide, indole and acetoin (VogesProskauer reaction), hydrolysis of casein, gelatin, starch, Tweens 20, 40 and 80, agar $(1.5 \%, w / v), D N A$, urea and cellulose (CM-cellulose and filter paper) and oxidase, catalase, $\beta$-galactosidase and alkaline phosphatase activities were carried out according to standard procedures (Gerhardt et al., 1994). Requirement of $\mathrm{NaCl}$ for growth was assessed on a solid medium, consisting of $\left(\mathrm{l}^{-1}\right.$ distilled water): $5 \mathrm{~g}$ Bacto peptone (Difco), $2 \mathrm{~g}$ Bacto yeast extract (Difco), 1 g glucose, $0.02 \mathrm{~g} \mathrm{KH}_{2} \mathrm{PO}_{4}, 0.05 \mathrm{~g} \mathrm{MgSO}_{4} .7 \mathrm{H}_{2} \mathrm{O}$ and $20 \mathrm{~g}$ Bacto agar (Difco), supplemented with 0, 1, 2, 3, $4,5,6,8,10$ or $12 \%(\mathrm{w} / \mathrm{v}) \mathrm{NaCl}$; growth was determined after 7 days of incubation at $28{ }^{\circ} \mathrm{C}$. Utilization of carbon sources was examined as described previously (Nedashkovskaya et al., 2003). Hydrolysis of chitin (1\%, $\mathrm{w} / \mathrm{v}$ ) was determined by the appearance of clear zones around colonies on chitin agar. The presence of flexirubin pigments in strain SCB36 ${ }^{\mathrm{T}}$ was determined by the method of Fautz \& Reichenbach (1980). Gliding motility was determined as described previously (Bowman, 2000). For studies of cell morphology, cells were grown at $21{ }^{\circ} \mathrm{C}$ in $\mathrm{MB}$ until early exponential growth phase $(35 \mathrm{~h}$ of incubation), when cells were fixed with glutaraldehyde and filtered onto $0.2 \mu \mathrm{m}$-pore-size polycarbonate filters (Nuclepore). Samples were treated by sequential ethanoldehydration steps, critical-point drying with $\mathrm{CO}_{2}$ and silver coating and viewed with a Hitachi S-3500N scanning electron microscope. Susceptibility to antibiotics was examined by the routine disc-diffusion plate method after 7 days of incubation on MA at $28{ }^{\circ} \mathrm{C}$. Discs were impregnated with the following antibiotics ( $\mu \mathrm{g}$ unless otherwise stated): ampicillin (10), benzylpenicillin (10 U), carbenicillin (100), chloramphenicol (30), doxycycline (10), erythromycin (15), gentamicin (10), kanamycin (30), lincomycin (15), neomycin (30), oleandomycin (15), polymyxin B (300 U), streptomycin (30) and tetracycline (30). Phenotypic characteristics of strain SCB $36^{\mathrm{T}}$ were determined in the same laboratory under the same conditions and using the same methodology as described previously for the type strains of three other Winogradskyella species (Nedashkovskaya et al., 2005). Cells of strain SCB $36^{\mathrm{T}}$ were Gram-reaction-negative single rods, approximately $0.3-0.4 \mu \mathrm{m}$ in diameter and $0.8-$ $1.8 \mu \mathrm{m}$ in length (Supplementary Fig. S2), motile by gliding, with a chemo-organotrophic respiratory type of metabolism. The abilities of strain $\mathrm{SCB} 36^{\mathrm{T}}$ to produce hydrogen sulfide and to form acid from glycerol distinguished it from other members of the genus Winogradskyella. Also, unlike most other Winogradskyella species, it was unable to degrade agar. Other physiological characteristics are given in Table 1 and in the species description.

Table 1. Differentiating phenotypic features of type strains of some Winogradskyella species

Strains: 1 , Winogradskyella rapida sp. nov. $\mathrm{SCB} 36^{\mathrm{T}} ; 2$, W. thalassocola KMM $3907^{\mathrm{T}}$; 3, W. epiphytica KMM $3906^{\mathrm{T}}$; 4, W. eximia KMM $3944^{\mathrm{T}}$; 5, W. poriferorum UST030701-295 ${ }^{\mathrm{T}}$. Data for reference strains were taken from Lau et al. (2005) (W. poriferorum UST030701-295 ${ }^{\mathrm{T}}$ ) or Nedashkovskaya et al. (2005) (remaining strains). All strains were positive for the following tests: chemo-organotrophic respiratory type of metabolism; gliding motility; oxidase, catalase and alkaline phosphatase activities; requirement for $\mathrm{Na}^{+}$ions for growth; hydrolysis of gelatin and Tween 40 . All strains were negative for the following tests: nitrate reductase and $\beta$-galactosidase activities; flexirubin-type pigment production; indole and acetoin production; hydrolysis of urea and chitin; acid production from L-arabinose, Dgalactose, lactose, melibiose, L-rhamnose, DL-xylose, adonitol, dulcitol, inositol, sorbitol and citrate; and utilization of L-arabinose, lactose, inositol, sorbitol, malonate and citrate. All strains were susceptible to carbenicillin and lincomycin and resistant to benzylpenicillin, gentamicin, kanamycin, neomycin, polymyxin $\mathrm{B}$ and streptomycin. +, Positive; -, negative; ND, no data available.

\begin{tabular}{|lccccc|}
\hline Characteristic & $\mathbf{1}$ & $\mathbf{2}$ & $\mathbf{3}$ & $\mathbf{4}$ & $\mathbf{5}$ \\
\hline Growth at/with: & & & & & \\
$37{ }^{\circ} \mathrm{C}$ & - & - & + & - & + \\
$44{ }^{\circ} \mathrm{C}$ & - & - & - & - & + \\
$8 \% \mathrm{NaCl}$ & + & + & + & - & - \\
Hydrogen sulfide production & + & - & - & - & - \\
Degradation of: & & & & & \\
Agar & - & + & + & + & - \\
Casein, starch & + & - & - & + & - \\
Tween 20 & + & - & + & + & + \\
Tween 80 & + & - & + & - & + \\
DNA & - & - & + & - & + \\
Acid formation from: & & & & & \\
D-Glucose, maltose & + & + & - & + & - \\
Cellobiose & - & + & - & - & - \\
Sucrose & - & - & - & + & - \\
Glycerol & + & - & - & - & - \\
Mannitol & + & - & - & + & - \\
Utilization of: & & & & & \\
D-Glucose, D-mannose & + & + & - & + & - \\
Sucrose & - & - & - & + & - \\
Mannitol & + & - & - & + & - \\
Susceptibility to: & & & & & \\
Ampicillin & + & - & + & - & + \\
Oleandomycin & + & + & + & - & $\mathrm{ND}$ \\
Tetracycline & + & + & + & + \\
DNA G+ C content (mol\%) & 36.3 & 34.6 & 35.2 & 36.1 & 32.8 \\
& & & & & \\
\hline
\end{tabular}


The API ZYM (bioMérieux) gallery was used to test for enzyme activities of the strain according to the manufacturer's instructions except that cells were suspended in a $3.5 \%$ sea-salt solution before inoculation of the API ZYM strips and the strips were incubated for $20 \mathrm{~h}$ at $20{ }^{\circ} \mathrm{C}$.

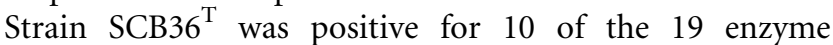
activities tested. The highest activities (value of 5 on a scale from 1 to 5) were recorded for leucine and valine arylamidases as well as alkaline phosphatase. The high values for arylamidases, particularly valine arylamidase, are notable considering that several gammaproteobacteria show lower activities, if any, for these enzymes (Arahal et al., 2007). We note that recent genome analyses of marine flavobacteria reveal comparatively large numbers of genes encoding peptidases (Bauer et al., 2006; González et al., 2008). These results suggest that the potential to hydrolyse polypeptides could help to explain the success of strain SCB36 ${ }^{\mathrm{T}}$ following the enrichment of seawater with dissolved protein.

For analysis of the fatty acid composition, strain $\mathrm{SCB} 36^{\mathrm{T}}$ was grown on MA at $28{ }^{\circ} \mathrm{C}$. When dense growth had developed $(24 \mathrm{~h})$, cells were harvested and the fatty acid composition was determined according to the standard protocol of the Microbial Identification System. Fatty acid analysis of strain $\mathrm{SCB} 36^{\mathrm{T}}$ was carried out in the same laboratory and under the same conditions and methodology as described previously for three other Winogradskyella species (Nedashkovskaya et al., 2005). The cellular fatty acid profile of strain SCB36 ${ }^{\mathrm{T}}$ differed markedly from those of the other Winogradskyella species in that the four dominant fatty acids, anteiso- $\mathrm{C}_{15: 0}$, iso$\mathrm{C}_{15: 0}$, iso- $\mathrm{C}_{15: 0} 3-\mathrm{OH}$ and iso- $\mathrm{C}_{15: 1}$, together accounted for $62 \%$ of the total fatty acids (each accounting for 14$18 \%$ of total), while iso- $\mathrm{C}_{16: 0} 3-\mathrm{OH}$ was only a minor component (Table 2).

For phylogenetic analysis, the genomic DNA was isolated following a standard phenol extraction protocol (Wilson, 1994). The 16S rRNA gene sequence was amplified by means of PCR using the primers $27 \mathrm{~F}$ and 1492R (Giovannoni, 1991). Sequencing of the 16S rRNA gene was carried out by Macrogen (Korea), using primers 27F and 1492R and the internal primer 907RM (Muyzer et al., 1998). The nearly complete 16S rRNA gene sequence of strain SCB36 ${ }^{\mathrm{T}}$ was 1478 nucleotides in length. CLUSTAL $\mathrm{W}$ was used to align the sequence with those from members of the family Flavobacteriaceae and a neighbour-joining phylogenetic tree was constructed with the MEGALIGN software in the DNASTAR package (version 7.0). As seen in Fig. 1, strain SCB $36^{\mathrm{T}}$ clustered with members of the genus Winogradskyella. The topology of the maximum-likelihood tree was essentially the same (data not shown). The $16 \mathrm{~S}$ rRNA gene sequence similarities of strain $\mathrm{SCB} 36^{\mathrm{T}}$ to Winogradskyella thalassocola $\mathrm{KMM} 3907^{\mathrm{T}}$ and to the other Winogradskyella type strains were 97.1 and 94.5-96.5\%, respectively. Sequence similarities to members of other genera of the Flavobacteriaceae ranged from 88.0 to $93.5 \%$. Thus, 16S rRNA gene sequence analysis suggested that
Table 2. Whole-cell fatty acid profiles of strain $\mathrm{SCB} 6^{\top}$ and the type strains of some other Winogradskyella species

Strains: 1, W. rapida sp. nov. SCB36 ${ }^{\mathrm{T}} ; 2$, W. thalassocola $\mathrm{KMM} 3907^{\mathrm{T}}$; 3, W. epiphytica KMM 3906 ${ }^{\mathrm{T}}$; 4, W. eximia $\mathrm{KMM} 3944^{\mathrm{T}}$; $5, W$. poriferorum UST030701-295 ${ }^{\mathrm{T}}$. Data for reference strains were taken from Lau et al. (2005) (W. poriferorum UST030701-295 ${ }^{\mathrm{T}}$ ) or Nedashkovskaya et al. (2005) (remaining strains). Fatty acids that comprise $<1 \%$ of the total for all strains are not given. tr, Traces $(<1 \%$ of total fatty acids).

\begin{tabular}{|c|c|c|c|c|c|}
\hline Fatty acid & 1 & 2 & 3 & 4 & 5 \\
\hline iso- $\mathrm{C}_{13: 0}$ & $\operatorname{tr}$ & - & - & - & 2.6 \\
\hline iso- $\mathrm{C}_{14: 0}$ & - & 2.6 & 4.5 & 1.4 & 1.2 \\
\hline iso- $\mathrm{C}_{14: 0} 3-\mathrm{OH}$ & - & $\operatorname{tr}$ & 1.6 & - & $\operatorname{tr}$ \\
\hline iso- $\mathrm{C}_{14: 1}$ & - & - & 1.4 & - & 2.0 \\
\hline $\mathrm{C}_{15: 0}$ & - & 7.9 & 1.2 & 6.7 & - \\
\hline anteiso- $\mathrm{C}_{15: 0}$ & 14.1 & 4.9 & 15.9 & 7.0 & - \\
\hline iso- $\mathrm{C}_{15: 0}$ & 18.5 & 8.7 & 6.7 & 25.6 & 12.6 \\
\hline iso- $\mathrm{C}_{15: 0} 3-\mathrm{OH}$ & 14.8 & 11.9 & 2.9 & 2.6 & 9.8 \\
\hline $\mathrm{C}_{15: 0} 2-\mathrm{OH}$ & 2.2 & 1.8 & 3.3 & 1.0 & 3.1 \\
\hline $\mathrm{C}_{15: 0} 3-\mathrm{OH}$ & 2.1 & 2.5 & - & - & 2.4 \\
\hline $\mathrm{C}_{15: 1} \omega 6 c$ & 3.8 & 6.5 & - & - & - \\
\hline anteiso- $\mathrm{C}_{15: 1}$ & 2.9 & 1.6 & 6.3 & 1.4 & 1.5 \\
\hline iso- $\mathrm{C}_{15: 1}$ & 14.6 & 11.4 & 8.1 & 10.4 & 20.9 \\
\hline 10-Methyl $C_{16: 0}$ & - & - & - & 6.3 & - \\
\hline $\mathrm{C}_{16: 0} 3-\mathrm{OH}$ & $\operatorname{tr}$ & 1.0 & - & - & 1.3 \\
\hline iso- $\mathrm{C}_{16: 0}$ & - & $\operatorname{tr}$ & 3.7 & 5.7 & $\operatorname{tr}$ \\
\hline iso- $\mathrm{C}_{16: 0} 3-\mathrm{OH}$ & 3.3 & 18.1 & 17.1 & 3.2 & 11.4 \\
\hline iso- $\mathrm{C}_{16: 1}$ & $\operatorname{tr}$ & 2.7 & 3.5 & 4.7 & $\operatorname{tr}$ \\
\hline $\mathrm{C}_{17: 0} 2-\mathrm{OH}$ & 2.7 & $\operatorname{tr}$ & 5.2 & 1.0 & $\operatorname{tr}$ \\
\hline $\mathrm{C}_{17: 0} 0$ cyclo & - & - & - & 2.3 & - \\
\hline iso- $\mathrm{C}_{17: 0} 3-\mathrm{OH}$ & 8.2 & 5.4 & 7.3 & 6.7 & 10.2 \\
\hline anteiso- $\mathrm{C}_{17: 1}$ & - & - & - & 2.3 & - \\
\hline iso- $\mathrm{C}_{17: 1} \omega 9 c$ & 1.5 & $\operatorname{tr}$ & 1.1 & - & - \\
\hline $\mathrm{C}_{17: 1} \omega 6 c$ & $\operatorname{tr}$ & $\operatorname{tr}$ & 1.9 & - & $\operatorname{tr}$ \\
\hline Summed feature $3^{*}$ & - & 4.2 & 5.1 & 6.1 & 9.8 \\
\hline
\end{tabular}

${ }^{*}$ Summed features represent groups of two or three fatty acids that could not be separated by GLC with the MIDI system. Summed feature 3 contained iso- $\mathrm{C}_{15: 0} 2-\mathrm{OH}$ and/or $\mathrm{C}_{16: 1} \omega 7 c$.

strain SCB36 ${ }^{\mathrm{T}}$ represents a novel species in the genus Winogradskyella.

For $\mathrm{G}+\mathrm{C}$ content determination and DNA-DNA hybridization, genomic DNA was extracted using the technique of Marmur (1961). DNA G $+C$ content was determined by the thermal denaturation method (Marmur \& Doty, 1962). The DNA G + C content of strain $\mathrm{SCB}^{\mathrm{T}}{ }^{\mathrm{T}}$ was $36.3 \mathrm{~mol} \%$, which is similar to or slightly higher than the values reported for the other Winogradskyella species (32.8$36.1 \mathrm{~mol} \%$; Nedashkovskaya et al., 2005; Lau et al., 2005). DNA-DNA hybridization experiments were performed spectrophotometrically using the initial renaturation rate method (De Ley et al., 1970). The level of DNA-DNA relatedness between strain $\mathrm{SCB} 36^{\mathrm{T}}$ and its closest relative in terms of $16 \mathrm{~S}$ rRNA gene sequence 


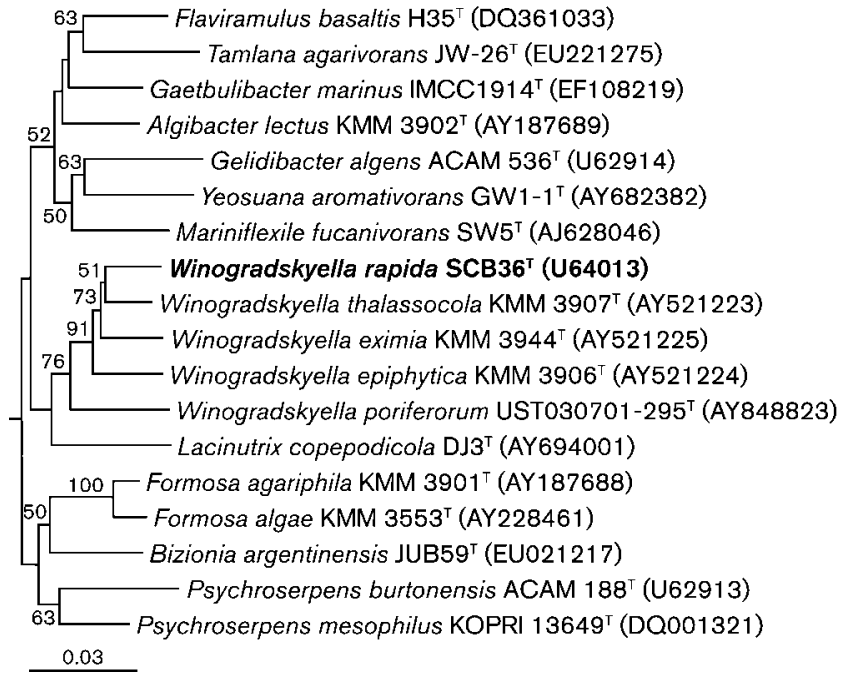

Fig. 1. Neighbour-joining phylogenetic tree based on $16 \mathrm{~S}$ rRNA gene sequence analysis of representative members of the family Flavobacteriaceae, showing the position of strain SCB36 ${ }^{\top}$. The sequence of Flexibacter flexilis ATCC $23079^{\top}$ (GenBank accession no. M62794) was used as the outgroup (not shown). Bootstrap values ( $>50 \%$ ) based on 1000 resamplings are shown at branch nodes. Bar, 0.03 substitutions per nucleotide position.

similarity, W. thalassocola $\mathrm{KMM} 3907^{\mathrm{T}}$, was $20 \%$. This substantiated the phylogenetic analysis and further supported our proposal of strain $\mathrm{SCB}^{\mathrm{T}} \mathrm{T}^{\mathrm{T}}$ as belonging to a novel Winogradskyella species.

A polyphasic approach showed that strain $\mathrm{SCB} 36^{\mathrm{T}}$ could be distinguished from recognized species of the genus Winogradskyella by a combination of genetic and phenotypic data and phylogenetic inference. We therefore conclude that this bacterium represents a novel species, for which the name Winogradskyella rapida sp. nov. is proposed.

\section{Description of Winogradskyella rapida sp. nov.}

Winogradskyella rapida (ra.pi'da. L. fem. adj. rapida fast, referring to the capacity for rapid growth in proteinenriched seawater).

Cells are $0.3-0.4 \mu \mathrm{m}$ in diameter and $0.8-1.8 \mu \mathrm{m}$ long. Colonies on MA are round, $2-3 \mathrm{~mm}$ in diameter and lightyellow-pigmented with a shiny surface. $\mathrm{Na}^{+}$ions are required for growth. Grows with 1-8\% $\mathrm{NaCl}$ (optimum $2-3 \%$ ) and at $4-36{ }^{\circ} \mathrm{C}$ (optimum $23-25{ }^{\circ} \mathrm{C}$ ). $\beta$ Galactosidase-negative. Nitrate is not reduced. Hydrogen sulfide is produced but indole and acetoin (VogesProskauer reaction) are not produced. Flexirubin-type pigments are not detected. Casein, gelatin, starch and Tweens 20, 40 and 80 are hydrolysed but agar, DNA, urea, cellulose (CM-cellulose and filter paper) and chitin are not hydrolysed. Acid is produced from D-glucose, maltose, Dfructose, glycerol and mannitol, but not from L-arabinose, cellobiose, D-galactose, lactose, melibiose, raffinose, Lrhamnose, sucrose, L-sorbose, trehalose, DL-xylose, $\mathrm{N}$ acetylglucosamine, adonitol, dulcitol, inositol, sorbitol or citrate. D-Mannose is utilized, but L-arabinose, lactose, inositol and sorbitol are not. According to the API ZYM gallery (bioMérieux), acid and alkaline phosphatases, esterase (C4), esterase lipase (C8), lipase (C14), leucine, valine and cystine arylamidases, trypsin, naphthol-AS-BIphosphohydrolase and $\alpha$-glucosidase activities are present, but $\alpha$-chymotrypsin, $\alpha$ - and $\beta$-galactosidases, $\beta$-glucuronidase, $\beta$-glucosidase, $N$-acetyl- $\beta$-glucosaminidase, $\alpha$-mannosidase and $\alpha$-fucosidase activities are absent. Susceptible to ampicillin, carbenicillin, chloramphenicol, doxycycline, erythromycin, lincomycin, oleandomycin and tetracycline. Resistant to benzylpenicillin, gentamicin, kanamycin, neomycin, polymyxin $\mathrm{B}$ and streptomycin. The main cellular fatty acids are antesio- $\mathrm{C}_{15: 0}$, iso- $\mathrm{C}_{15: 0}$, iso- $\mathrm{C}_{15: 0}$ $3-\mathrm{OH}$, iso- $\mathrm{C}_{15: 1}$ and iso- $\mathrm{C}_{17: 0} 3-\mathrm{OH}$. The DNA $\mathrm{G}+\mathrm{C}$ content of the type strain is $36.3 \mathrm{~mol} \%$.

The type strain, SCB36 ${ }^{\mathrm{T}}\left(=\mathrm{CECT} 7392^{\mathrm{T}}=\right.$ CCUG $\left.56098^{\mathrm{T}}\right)$, was isolated from a protein-enriched surface seawater sample from Scripps Pier (La Jolla, CA, USA), in the Eastern Pacific Ocean.

\section{Acknowledgements}

We thank Farooq Azam at Scripps Institution of Oceanography for his kind support during our visit to his laboratory, Sabina Arnautovic for technical assistance, Jean P. Euzéby for helpful advice with Latin names and Itziar Lekunberri and José Manuel Fortuño for scanning electron microscopy photography. We are grateful for the constructive critiques and comments from the anonymous reviewers. This work was supported by the Swedish Research Council (grant no. 6212003-2692 to J. P.). O. I. N. acknowledges the Russian Foundation for Basic Research (RFBR) for grant no. 08-04-00099.

\section{References}

Abell, G. C. J. \& Bowman, J. P. (2005). Colonization and community dynamics of class Flavobacteria on diatom detritus in experimental mesocosms based on Southern Ocean seawater. FEMS Microbiol Ecol 53, 379-391.

Alonso, C., Warnecke, F., Amann, R. \& Pernthaler, J. (2007). High local and global diversity of Flavobacteria in marine plankton. Environ Microbiol 9, 1253-1266.

Arahal, D. R., Lekunberri, I., Gonzalez, J. M., Pascual, J., Pujalte, M. J., Pedros-Alio, C. \& Pinhassi, J. (2007). Neptuniibacter caesariensis gen. nov., sp nov., a novel marine genome-sequenced gammaproteobacterium. Int J Syst Evol Microbiol 57, 1000-1006.

Bauer, M., Kube, M., Teeling, H., Richter, M., Lombardot, T., Allers, E., Würdemann, C. A., Quast, C., Kuhl, H. \& other authors (2006). Whole genome analysis of the marine Bacteroidetes 'Gramella forsetii' reveals adaptations to degradation of polymeric organic matter. Environ Microbiol 8, 2201-2213.

Bowman, J. P. (2000). Description of Cellulophaga algicola sp. nov., isolated from the surfaces of Antarctic algae, and reclassification of Cytophaga uliginosa (ZoBell and Upham 1944) Reichenbach 1989 as Cellulophaga uliginosa comb. nov. Int J Syst Evol Microbiol 50, 1861-1868. 
Cottrell, M. T. \& Kirchman, D. L. (2000). Natural assemblages of marine proteobacteria and members of the Cytophaga-Flavobacter cluster consuming low- and high-molecular-weight dissolved organic matter. Appl Environ Microbiol 66, 1692-1697.

De Ley, J., Cattoir, H. \& Reynaerts, A. (1970). The quantitative measurement of DNA hybridization from renaturation rates. Eur $J$ Biochem 12, 133-142.

Fautz, E. \& Reichenbach, H. (1980). A simple test for flexirubin-type pigments. FEMS Microbiol Lett 8, 87-91.

Gerhardt, P., Murray, R. G. E., Wood, W. A. \& Krieg, N. R. (editors) (1994). Methods for General and Molecular Bacteriology. Washington, DC: American Society for Microbiology.

Giovannoni, S. J. (1991). The polymerase chain reaction. In Nucleic Acid Techniques in Bacterial Systematics, pp. 177-201. Edited by E. Stackebrandt \& M. Goodfellow. Chichester: Wiley.

Glöckner, F. O., Fuchs, B. M. \& Amann, R. (1999). Bacterioplankton composition of lakes and oceans: a first comparison based on fluorescence in situ hybridization. Appl Environ Microbiol 65, 37213726.

González, J. M., Fernández-Gómez, B., Fernàndez-Guerra, A., Gómez-Consarnau, L., Sánchez, O., Coll-Lladó, M., Del Campo, J., Escudero, L., Rodriguez-Martínez, R. \& other authors (2008). Genome analysis of the proteorhodopsin-containing marine bacterium Polaribacter sp. MED152 (Flavobacteria). Proc Natl Acad Sci U S A 105, 8724-8729.

Kirchman, D. L. (2002). The ecology of Cytophaga-Flavobacteria in aquatic environments. FEMS Microbiol Ecol 39, 91-100.

Lau, S. C. K., Tsoi, M. M. Y., Li, X. C., Plakhotnikova, I., Dobretsov, S., Lau, K. W., Wu, M., Wong, P. K., Pawlik, J. R. \& other authors (2005). Winogradskyella poriferorum sp nov., a novel member of the family Flavobacteriaceae isolated from a sponge in the Bahamas. Int J Syst Evol Microbiol 55, 1589-1592.
Marmur, J. (1961). A procedure for the isolation of deoxyribonucleic acid from microorganisms. J Mol Biol 3, 208-218.

Marmur, J. \& Doty, P. (1962). Determination of the base composition of deoxyribonucleic acid from its thermal denaturation temperature. J Mol Biol 5, 109-118.

Muyzer, G., Brinkhoff, T., Nübel, U., Santegoeds, C., Schäfer, H. \& Wawer, C. (1998). Denaturing gradient gel electrophoresis (DGGE) in microbial ecology. In Molecular Microbial Ecology Manual, vol. 3.4.4, pp. 1-27. Edited by A. D. L. Akkermans, J. D. van Elsas \& F. J. de Bruijn. Dordrecht: Kluwer.

Nedashkovskaya, O. I., Suzuki, M., Vysotski, M. V. \& Mikhailov, V. V. (2003). Reichenbachia agariperforans gen. nov., sp. nov., a novel marine bacterium in the phylum Cytophaga-FlavobacteriumBacteroides. Int J Syst Evol Microbiol 53, 81-85.

Nedashkovskaya, O. I., Kim, S. B., Han, S. K., Snauwaert, C., Vancanneyt, M., Swings, J., Kim, K. O., Lysenko, A. M., Rohde, M. \& other authors (2005). Winogradskyella thalassocola gen. nov., sp. nov., Winogradskyella epiphytica sp. nov. and Winogradskyella eximia sp. nov., marine bacteria of the family Flavobacteriaceae. Int J Syst Evol Microbiol 55, 49-55.

Pinhassi, J., Azam, F., Hemphälä, J., Long, R. A., Martinez, J., Zweifel, U. L. \& Hagström, A. (1999). Coupling between bacterioplankton species composition, population dynamics, and organic matter degradation. Aquat Microb Ecol 17, 13-26.

Pinhassi, J., Sala, M. M., Havskum, H., Peters, F., Guadayol, Ò., Malits, A. \& Marrasé, C. (2004). Changes in bacterioplankton composition under different phytoplankton regimens. Appl Environ Microbiol 70, 6753-6766.

Wilson, K. (1994). Preparation of genomic DNA from bacteria. In Current Protocols in Molecular Biology, pp. 2.4.1-2.4.2. Edited by F. M. Ausubel, R. Brent, R. E. Kingston, D. D. Moore, J. G. Seidman, J. A. Smith \& K. Struhl. New York: Green Publishing \& Wiley-Interscience. 